\title{
噴門部癌切除症例の検討
}

\begin{tabular}{|c|c|c|c|c|c|c|}
\hline \multicolumn{7}{|c|}{ 岐皁大学医学部第 2 外科, 岐阜市民病院外科* } \\
\hline 種才 & 広已 & 田中 & 千凱** & 伊藤 隆夫* & 大橋 & 広文 \\
\hline & 董豊 & 古田 & 智彦 & 松村幸次郎* & 東 & \\
\hline & 良 & 深田 & 代造 & 坂田 一記 & & \\
\hline
\end{tabular}

\section{CLINICAL ANALYSIS OF THE RESECTABLE GASTRIC CANCER IN THE CARDIAC REGION}

\author{
Hiromi TANEMURA, Sengai TANAKA*, Takao ITO* \\ Hirofumi OHASHI, Shigetoyo SAJI, Tomohiko FURUTA, \\ Kojiro MATSUMURA*, Shuji AZUMA, Ryo KAWATA, \\ Daizo FUKATA and Kazuki SAKATA \\ 2nd Department of Surgery, Gifu University School of Medicine \\ Department of Surgery, Gifu City Hospital*
}

\begin{abstract}
噴門部癌 (E-G junctionの上下 $2 \mathrm{~cm}$ 以内に癌の中心を有するもの) についての特殊性を検討する目 的で, 広範進展例を除く胃癌手術例891例を噴門部癌, 上部, 中部, 下部胃癌に分け, 性別, 年齢, 手 術結果, 予後について検討し以下の結論を得た。1）噴門部癌は高龄の男性に多い，2）分化型腺癌が 多く，浆膜漫潤 $(72.2 \%)$ ，リンパ節転移 $(77.8 \%)$ が高率にみられ高度進行例が多い。3）腫瘍径の 比較的小さい症例でもすでに㓡膜浸潤 (62.5\%)，リンバ節転移 (62.5\%) がみられ高度進行例が多い. 4）噴門部癌の 5 生率は治瘏切除例でも $30.3 \%$ と他領域胃癌に比べ不良で, 食道漫潤例の 5 生率は $23.0 \%$ とさらに不良である。
\end{abstract}

象引用語：噴門部癌，噴門部癌の特殊性，噴門部癌食道漫潤

はじめに

噴門部癌は現行の胃癌取り扱い規約により, 胃の上 部1/3を占拠する上部胃癌 ( C 領域) に包括される.乙 かし種々解剖学的特性をるった噴門部癌が他の上部胃 癌あるいは中・下部胃癌と比較し, 癌の進展様式, 予 後などいろいろな点で特殊性のあることが報告され， 第43回胃癌研究会 (前橋) でも噴門部癌の特殊性が主 題として取り上げられ議論された。

今回著者らは過去 12 年間に扱った胃癌切除症例を対 象に, 噴門部癌の手術結果, 予後などを他の領域胃癌 と比較検討したので報告する。

検討症例书よび方法

検討対象症例は1972年〜1983年までに岐皁大学第 2

<1985年12月11日受理 >別刷請求先：種村 広已 $\overline{\mathrm{T}} 500$ 岐阜市司町 40 岐阜大学医学部第 2 外科
外科扣よび岐阜市民病院外科にて切除した胃癌症例 891例を対象とした。ただし重複癌，多発癌，3領域に またがる広範進展例は除外した。これら891例を胃癌取 り扱い規約1)にしたがい上部胃癌, 中部胃癌, 下部胃癌 に分類し，さらにこの広義の上部胃癌を西ら ${ }^{2)}$ の噴門 部癌の定義にしたがい, EG (esophago-gastric) junctionを中心に上下 $2 \mathrm{~cm}$ 以内に癌の中心があるすのを 噴門部癌として別に取り扱い，それ以外の胃上部に主 占拠部位を有するものをここでは上部胃癌とした。

これら各領域別に性別, 年龄, 手術成績, 組織型, 進行程度, 予後について比較検討した。

生存率は標準誤差に基づく方法にて累積生存率とし て算定し, 有意差検定は $\chi^{2}$ 検定括よび $\mathrm{t}$-検定にて行っ た.

1. 噴門部癌の頻度 
各領域別症例数は表 1 のごとくであり,891例中噴門 部癌は36例, 上部胃癌73例, 中部胃癌347例, 下部胃癌 435例で，噴門部癌の頻度は $4.0 \%$ あっった。

2. 性別対比および年齢分布

各領域別性別対比は表 2 のごとくで，各領域の男性 の占める頻度は噴門部癌が $77.8 \%$, 上部胃癌 $56.2 \%$, 中部胃癌 $61.1 \%$, 下部胃癌 $67.6 \%$ であり，噴門部癌で は男性の占める割合が他領域に比べ高く, 特に上部胃 癌, 中部胃癌に対してはそれぞれ $\mathrm{p}<0.01, \mathrm{p}<0.05 の$ 有意差をるって高かった。

年齢分布では表 3 のごとく噴門部癌と下部胃癌の平 均年齢がそれぞれ60.9歳, 60.1歳であるのに対し，上 部，中部胃癌の平均年齢はそれぞれ53.6歳，56.2歳で あり, 前 2 領域は後 2 領域に比べ有意に高かった.

3. 手術結果

噴門部癌36例に対して 31 例に胃全摘，5例に噴門側 切除を行った. 上部胃癌73例については胃全摘62例， 噴門側切除 3 例，幽門側要全摘11例であった，食道浸 潤例は噴門部癌 36 例中 16 例に認め, $5 ち 3$ 例開胸開 腹術を行い, 上部胃癌は73例中 13 例に食道浸潤を認め, らち 2 例に開胸開腹， 1 例に胸骨縦切開を行った。膵 体尾部合併切除を行った症例は噴門部，上部胃癌をあ わせた109例中40例（36.7\%）であった。

a) 根治度

表 1 対象症例

\begin{tabular}{|c|c|c|c|}
\hline 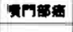 & 上部舴啬 & 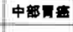 & 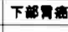 \\
\hline 36 & 73 & 347 & 435 \\
\hline
\end{tabular}

表 2 各領域胃癌の性別対比

\begin{tabular}{|c|c|c|}
\hline 伤 & f & ㅇ \\
\hline 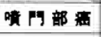 & $r 28 / 36(77.8)$ & $8 / 36 \quad(22.2$ \\
\hline 上部而雷 & $6-41 / 73 \quad(56.2)$ & $=32 / 73 \quad(43.8)$ \\
\hline 中部田憲 & $212 / 347(61.1)$ & $135 / 347(38.9)$ \\
\hline 下部回艒 & $294 / 435(67.6)$ & $141 / 435(32.4)$ \\
\hline
\end{tabular}

\section{表 3 各領域胃癌の年齢構成}

\begin{tabular}{|c|c|c|c|c|c|c|c|c|}
\hline 年 & $20-29$ & $30 \sim 39$ & $40-49$ & $50 \sim 59$ & $60 \sim 69$ & $70 \sim 79$ & $100-89$ & Mean \pm SD \\
\hline 唭門部视 & & $\begin{array}{c}1 \\
(2.8)\end{array}$ & (11.1) & $\begin{array}{c}10 \\
(27.8)\end{array}$ & $\begin{array}{c}13 \\
(36.1)\end{array}$ & $\begin{array}{c}8 \\
(22.2)\end{array}$ & & $30.9 \pm 10.2$ \\
\hline 上部骨露 & $\stackrel{2}{(2.7)}$ & $\stackrel{9}{9}$ & $\begin{array}{c}19 \\
(26.0)\end{array}$ & $\begin{array}{c}19 \\
(26.0)\end{array}$ & $\begin{array}{c}16 \\
\text { (21.9) }\end{array}$ & $\begin{array}{c}8 \\
\text { (11.0) }\end{array}$ & & 12.5 \\
\hline 中部同雷 & $\begin{array}{c}10 \\
(2.9)\end{array}$ & $\begin{array}{c}33 \\
(9.5)\end{array}$ & $\begin{array}{c}62 \\
(17.9) \\
\end{array}$ & $\begin{array}{c}96 \\
(27.7)\end{array}$ & $\begin{array}{c}86 \\
(24.8)\end{array}$ & $\begin{array}{c}56 \\
(16.1)\end{array}$ & (1.2) & 12.8 \\
\hline 下部闻事 & $\begin{array}{c}5 \\
(1.1)\end{array}$ & $\begin{array}{c}20 \\
(4.6)\end{array}$ & $\begin{array}{c}50 \\
\text { (11.5) }\end{array}$ & $\begin{array}{c}123 \\
(28.3) \\
\end{array}$ & $\begin{array}{c}145 \\
(33.3)\end{array}$ & $\begin{array}{c}83 \\
(19.1) \\
\end{array}$ & $\begin{array}{c}9 \\
(2.1)\end{array}$ & $60.1 \pm 11.3$ \\
\hline
\end{tabular}

各領域別治疾切除率は図 1 のごとく噴門部癌 $69.4 \%$, 上部胃癌 $60.3 \%$, 中部胃癌 $79.0 \%$, 下部胃癌 $65.5 \%$ と部胃癌で最も不良で，噴門部癌ではむしろ 比較的良好な成績であった。

非治痹切除となった因子を検討すると，噴門部癌て は ow (十)のために非治㾤切除となった症例が非治瘜 切除例11例中 4 例 $(36.4 \%)$ にみられ，他領域の胃癌 に比べ ow (十) の頻度が最も高かった。一方 $\mathrm{R}<\mathrm{n}, \mathrm{P}$ (+), H (+) であった症例はそれぞれ 6 例 $(54.5 \%)$ ， 5 例 $(45.5 \%), 1$ 例 $(9.1 \%)$ であり他領域胃癌に比 べその頻度は低かった。

b）肉眼的病型

肉眼的に進行癌と判定した症例の肉眼的病型分類は Borrmann 1, 2 の限局型が噴門部癌10例 (31.3\%)，上 部胃癌18例 (31.0\%)，中部胃癌53例 $(29.4 \%)$, 下部 胃癌 120 例 (39.2\%) であり, Borrmann 3，4の漫潤型 は乞れぞれ22例 $(68.7 \%) ， 40$ 例 (68.9\%)，127例

図 1 治瘦切除率

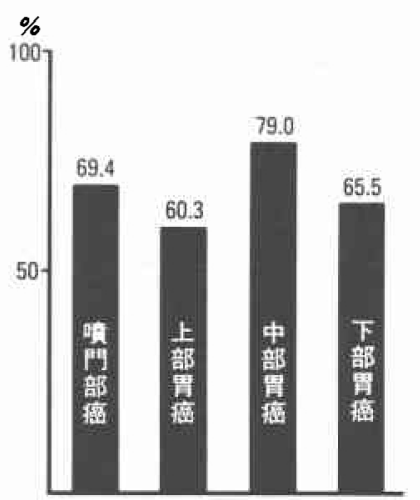

図 2 各領域と進行程度の関係
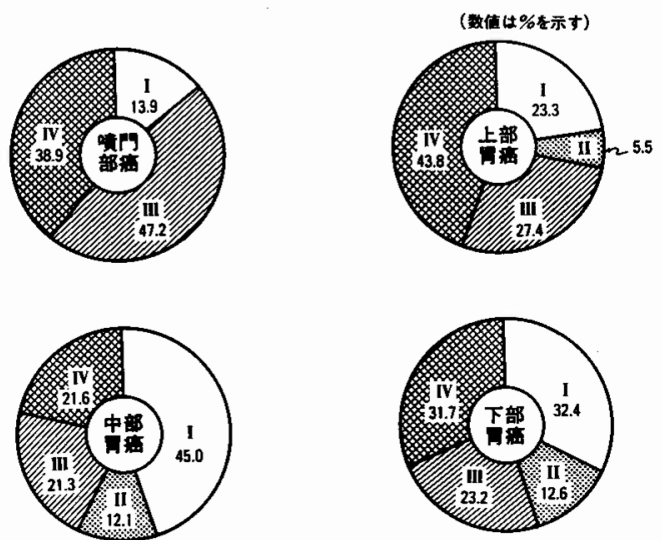
(70.6\%)，186例 (61.0\%) であり，噴門部癌と他領域 胃癌との間に差はみられなかった。

c) 進行程度

各領域胃癌の進行程度別割合を比較すると図 2 のご とく噴門部癌では stage I $13.9 \%$, II $0 \%$, III $47.2 \%$, IV $38.9 \%$ であり，上部胃癌ではI $23.3 \%$, II $5.5 \%$, III $27.4 \%$, IV $43.8 \%$ で, どちらす stage III, IV 症例 がそれぞれ $86.1 \% ， 71.2 \%$ 占め大多数が進行程度の 進んだ症例であったのに対し, 中部胃癌ではstage I $45.0 \%$, II $12.1 \%$, III $21.3 \%$, IV $21.6 \%$, 下部胃癌 ではI $32.4 \%$, II $12.6 \%$, III $23.2 \%$, IV $31.7 \%$ あ り, stage III, IV 症例はそれぞれ $42.9 \%, 54.9 \%$ にと と゚まり, 噴門部癌, 上部胃癌は中部, 下部胃癌に比べ 有意 $(\mathrm{p}<0.01)$ に stage III, IV の進行癌が多かった.

一方進行程度決定因子別に各領域胃癌を比較する と, 組織学的深達度別 (表 4) では, 噴門部癌では36 例中26例 $(72.2 \%)$ 予後的浆膜面因子陽性 (ps+) で,しかもその全例が se またはsi (sei) と㓡膜露出ま たは他臓器漫潤例であった。一方 sm までの表在癌は 2 例 (5.6\%) にすぎなかった。 上部胃癌も ps (十) 例 が74.0\%にみられたが sm までの表在癌も $16.4 \%$ にみ られた。中部胃癌の ps (+) 例は $45.0 \%$, 下部胃癌で は53.1\%であり，噴門部癌および上部胃癌では中，下 部胃癌に比べ有意 $(\mathrm{p}<0.01 \sim 0.05)$ K $\mathrm{ps}(+)$ 例の頻 度が高かった。

リンパ節転移陽性率は図 3 のごとく噴門部癌 $77.8 \%$, 上部胃癌 $61.6 \%$, 中部胃癌 $44.4 \%$, 下部胃癌 $61.4 \%$ と噴門部癌で最も高く, 特に噴門部癌と中部胃 癌のリンパ節転移率の間には $\mathrm{p}<0.01 て ゙$ 有意差を認め た。をた 2 群以上のリンパ節転移陽性例は，噴門部癌， 上部胃癌で $50.5 \%, 50.7 \%$ であり，注涪半数の症例で 広範なリンパ節転移がみられたのに対し，中部，下部 胃癌ではそれぞれ $23.9 \% ， 40.0 \%$ にずなかった。

表 4 各領域胃癌の組織学的深達度

\begin{tabular}{|c|c|c|c|c|c|c|c|c|}
\hline \multirow{2}{*}{ 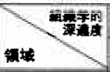 } & \multicolumn{5}{|c|}{ ps $H$} & \multicolumn{2}{|r|}{ ps $(t)$} & \multirow{2}{*}{ 不明 } \\
\hline & m & sm I & $\mathrm{pm}$ & ss $\alpha$ & $\mathrm{ss} \beta$ & $5 s \gamma$ & se si (soi) & \\
\hline \multirow{2}{*}{ 晴年部雷 } & 2 & 0 & 4 & 3 & 1 & & 19 & 0 \\
\hline & \multicolumn{5}{|c|}{$10 / 36(27.8)$} & \multicolumn{2}{|c|}{ (1) $26 / 36(72.2)$} & \\
\hline \multirow{2}{*}{ 上部同赢 } & 5 & 7 & 5 & 1 & 1 & 3 & $29 \quad 22$ & 0 \\
\hline & \multicolumn{5}{|c|}{$19 / 73(26.0)$} & \multicolumn{2}{|c|}{ (254/73(74.0) } & \\
\hline \multirow{2}{*}{ 中部同盍 } & 84 & 54 & 32 & 10 & 9 & 19 & $105 \quad 32$ & 2 \\
\hline & \multicolumn{5}{|c|}{$189 / 347(52.2)$} & \multicolumn{2}{|c|}{$9156 / 347(45.0)$} & \\
\hline \multirow{2}{*}{ 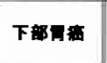 } & 65 & 53 & 57 & 14 & 15 & 23 & $179 \quad 29$ & 0 \\
\hline & \multicolumn{5}{|c|}{$204 / 435(46.9)$} & \multicolumn{2}{|c|}{$231 / 435(53.1)$} & \\
\hline & & & & 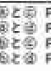 & $\begin{array}{l}P<0001 \\
P<005 \\
P<001 \\
P<0.01\end{array}$ & 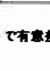 & 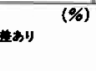 & \\
\hline
\end{tabular}

そのほか肝転移 $\mathrm{H}(+)$ 症例については，噴門部癌 $5.6 \%$, 上部 $2.7 \%$, 中部 $4.3 \%$, 下部 $7.1 \%$ と下部胃癌 と噴門部癌に若干多い傾向であった。一方腹膜転移 $\mathrm{P}$ (+)症例については噴門部癌 $13.9 \%$, 上部 $20.5 \%$, 中 部10.7\%, 下部 $18.6 \%$ と噴門部，中部胃癌に少ない傾 向であった。

$\mathrm{R}_{2}$ 以上手術例における各リンパ節への転移率を噴 門部癌, 上部胃癌で比較した結果, 図 4 のごとく噴門 部癌では右噴門リンパ節, 左噴門リンパ節，小弯リン

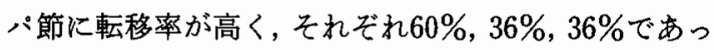
た。ついで左胃動脈幹リンパ節，総肝動脈幹リンパ節 にそれぞれ $12 \%$ の転移率を認めた.脾動脈幹リンパ節, 脾門部リンパ節転移率はそれぞれ $8 \%$ であった。一方

因 3 各領域胃癌の予後因子別比較
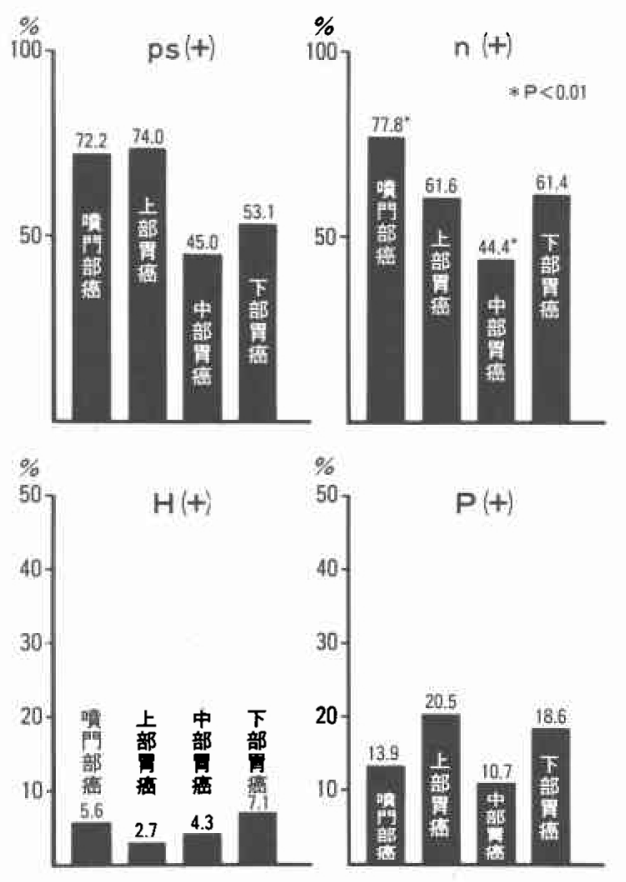

目 $4 \mathrm{R}_{2}$ 以上リンパ節郭清例の各リンパ節別転移率
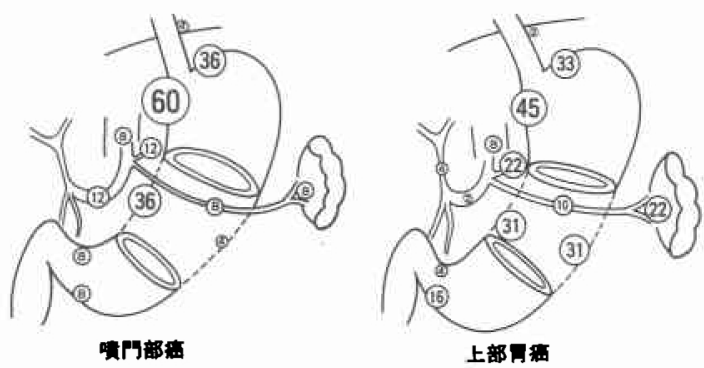
上部胃癌では右嘪門リンパ節，左噴門リンパ節，小弯 リンパ節に加光大弯リンパ節への転移率が高く，それ

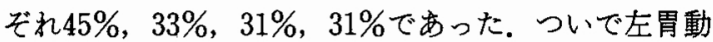
脈幹, 脾門部リンパ節にも $22 \%$ の転移率を認め,さら に幽門下リンパ節, 脾動脈幹リンパ節にそれぞれ16\%, $10 \%$ の転移率を認めた。

以上より噴門部癌では，小弯側から左胃動脈幹, 総 肝動脈幹リンパ節への進展が主体であるのに対し, 上 部胃癌では噴門部癌よりさらに広範で, 大弯, 脾門部, 幽門下リンパ節への転移もみられた。なお開胸あるい は胸骨縦切開を追加し胸腔内リンパ節廊清を行った症 例は噴門部癌で 3 例, 上部胃癌で 3 例であったが，噴 門部癌の 3 例中 1 例に胸部下部傍食道リンパ節110, 気 管分岐部リンパ節四に転移を認め, 上部胃癌の 3 例中

1 例に横隔膜リンパ節田に転移を認めた。

d）組織型

図 5 各領域と組織型の関保

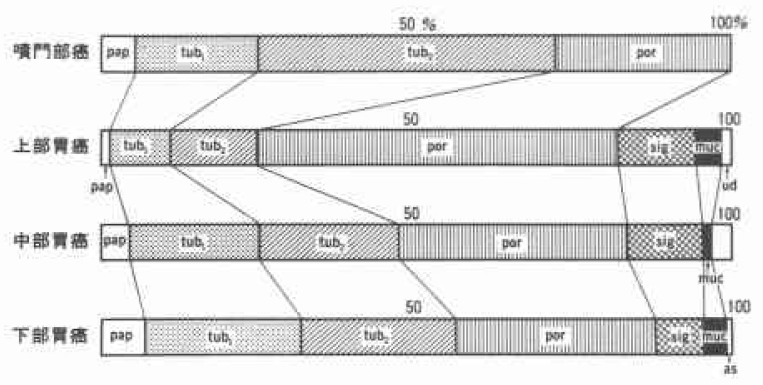

図 6 INF, v, ly 因子別比較検討

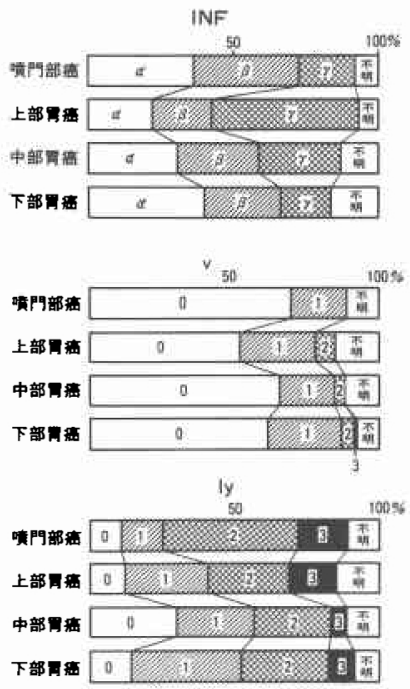

図 5 に各領域胃癌の組織型分布を示したが，噴門部 癌では高・中分化型腺癌が72.2\%を占め, 低分化型腺 癌は $27.8 \%$ にすぎず，未分化型癌（sig，muc）は 1 例 もみられなかった。逆に上部胃癌では高・中分化型腺 癌 $24.7 \%$ と少なく，低分化型腺癌が57.5\%を占め，未 分化型癌も $16.4 \%$ によれた。一方中部胃癌では高・ 中分化型腺癌が $47.3 \%$, 低分化型腺癌 $36.3 \%$ ，未分化 型癌 $15.9 \%$ でり，下部胃癌では $56.3 \% ， 31.7 \%$, $11.1 \%$ あった。 以上の結果より, 噴門部癌は大多数 が高・中分化型腺癌であるのに対し，上部胃癌では低 分化型腺癌が最も多く，他領域に比較しても高率で あった。

INF，v，ly 因子別の比較検討では，上部胃癌で他領 域に比べINF $\gamma$ の頻度が最も高率であり，噴門部癌が 最子低率であった以外著差を認めなかった（図6）.

e）主病巣の大きさと進行程度との関係

噴門部癌では全例が最大径 $9 \mathrm{~cm}$ 未満であったが，そ のうち一般に予後良好と思われる最大径が $5 \mathrm{~cm}$ 末満 症例16例について進行程度, リンパ節転移率, 予後的 采膜面因子について他領域胃癌と比較検討してみた. まず進行程度について検討した結果, 図7のごとく噴 門部癌では主病巣の最大径 $5 \mathrm{~cm}$ 末満で stage III また

\section{困 7 腫瘍径 $5 \mathrm{~cm}$ 末満症例と進行程度との関係}

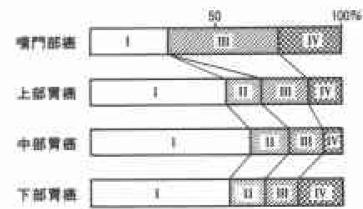

図 8 腫瘍径 $5 \mathrm{~cm}$ 未満症例とリンパ節転移との関係

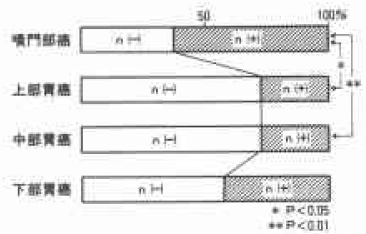

図 9 腫瘍径 $5 \mathrm{~cm}$ 末満症例と予後的缐膜面因子の関 係

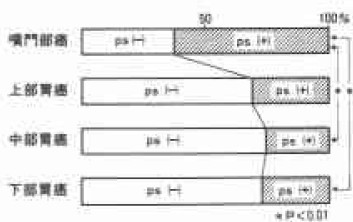




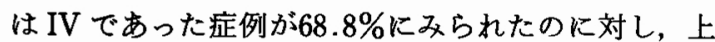
部胃癌では31.8\%, 中部胃癌では21.4\%, 下部胃癌で は30.5\%にすぎず，噴門部癌では他領域胃癌に比べ有 意 $(\mathrm{p}<0.01 \sim 0.05)$ に進行癌が多かった.

$5 \mathrm{~cm}$ 末満症例のリンパ節転移率については, 図 8 の ごとく噴門部癌で $62.5 \%$ n（十）例であったのに対 し, 上部胃癌では $27.3 \%$, 中部胃癌では $27.4 \%$, 下部 胃癌では $42.4 \%$ と噴門部癌では他領域胃癌に比ベリン パ節転移例が多かった。特に上部胃癌，中部胃癌に対 してはそれぞれ $\mathrm{p}<0.05, \mathrm{p}<0.01 て ゙$ 有意差を認めた。

また $5 \mathrm{~cm}$ 末満症例の予後的浆膜面因子（ps）につい て検討した結果，図 9 のことく ps（十）症例の頻度は

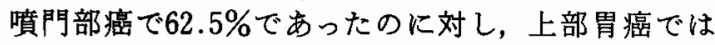
$31.8 \%$, 中部胃癌では $25.4 \%$, 下部胃癌では $27.1 \%$ と 噴門部癌では他領域胃癌に比べps (+) 症例が多く, 特に中部，下部胃癌に対しては $\mathrm{p}<0.01$ で有意差を認 めた。

以上の結果上り噴門部癌では，尰瘍最大径 $5 \mathrm{~cm}$ 末満 ですすでに過半数例が予後的浆膜面因子陽性であり, リンパ節転移も認め, stage も進んだ症例であること が判明した。

4. 予後

各領域胃癌の直死例を除いた耐術症例数は，噴門部 癌29例, 上部胃癌68例, 中部胃癌 333 例, 下部胃癌 410 例であった。これら耐術例について累積生存率を検討 すると図10のごとくで，その 3 生率，5生率は，噴門 部癌 $32.3 \%, 32.3 \%$, 上部胃癌 $56.1 \%, 43.4 \%$, 中部 胃癌 $63.7 \%, 60.8 \%$, 下部胃癌 $55.1 \%, 48.2 \%$ であり， 噴門部癌で最も予後不良で, 中部胃癌で最も予後が良 好であり, その両者間に $\mathrm{p}<0.025 て ゙$ 有意差を認めた。

さらにこれら各領域胃癌の予後を治瘾切除例に限っ て検討した結果, 図11のごとく噴門部癌の生存曲線と 他の領域胃癌の生存曲線の格差がさらに明らかとなっ

\section{因10 各領域胃癌の予後（累積生存率）}

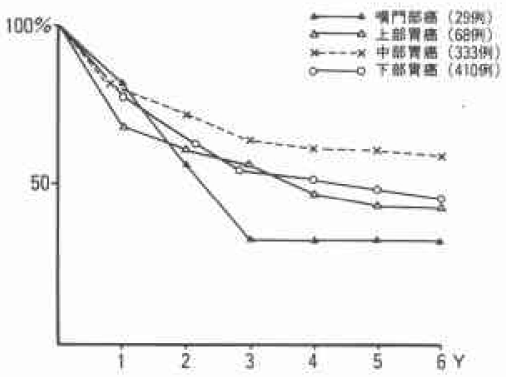

図11 治瘁切除例の予後（累積生存率）

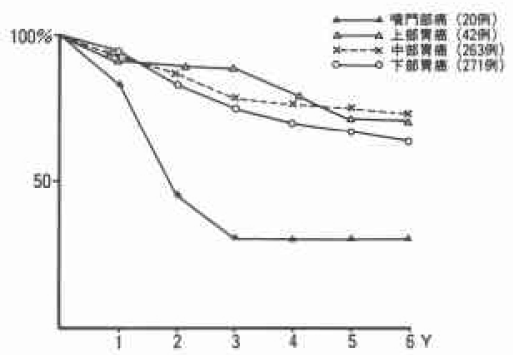

図12 食道への癌漫潤の有無による噴門部癌の予後の 比較

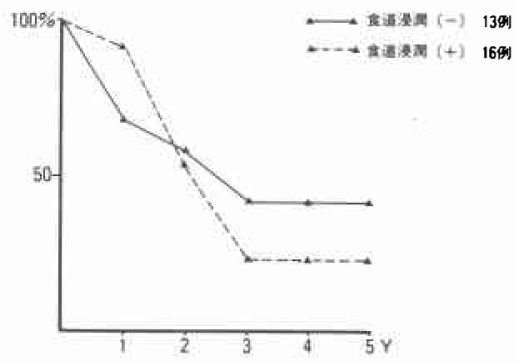

た. 各領域胃癌の 3 生率, 5 生率は, 噴門部癌で $30.3 \%$, $30.3 \%$, 上部胃癌 $88.9 \%, 71.6 \%$, 中部胃癌 $78.5 \%$, $75.4 \%$, 下部胃癌 $75.3 \%, 67.0 \%$ であり，噴門部癌の 3 生率, 5 生率は他領域のそれに比べ有意（ $\mathrm{p}<$ 0.005〜0.025）に低かった。

一方噴門部癌の予後を食道への癌浸潤陽性例 $(\mathrm{E}+)$ と陰性例 (E-) とに分けて検討した結果, 図12のごと く $\mathrm{E}($ ( ) 例では $41.6 \%$ の 5 年生存率がみられ上部胃 癌, 下部胃癌の 5 生率にほ注匹敵したのに対し, E (+) 例の 5 年生存率は $23.0 \%$ と不良であった。

以上の結果より噴門部癌では, 胃癌取り扱い規約上 治瘾切除となってもその予後は他領域胃癌に比へ極め て不良であった。

\section{考察}

食道胃接合部（E-G junction）付近に発生した癌は, 現行の胃癌取り扱い規約 ${ }^{1}$ によれば上部胃癌 ( C 領域) の中に包括される。しかし西らは E-G junctionを境に 上下打の打の $2 \mathrm{~cm}$ 以内に癌の中心を有するものを噴 門部癌と規定し，それを下部食道癌，上部胃癌と区別 し，独立した疾患として取り扱い検討することを提唱 している2). その後, 非噴門部上部胃癌やそのほかの 中・下部胃癌を対照にした噴門部癌の特殊性を論じた 報告がいくつかみられる3) 5)．著者らも上記のごとく 
E-G junction 境に上下 $2 \mathrm{~cm}$ 以内に癌の中心を有し た症例を噴門部癌と規定し, それ以外の上部胃癌, 中 部胃癌, 下部胃癌を対照とし検討した。

噴門部癌の頻度については，著者らの検討で，広範 進展例を除く全胃癌症例のうち $4.0 \%$ あっったが, 第 43 回胃癌研究会での各施設からの報告では噴門部癌の頻 度について $1.2 \%$ か $9.7 \%$ ま゙さまざすでおおむね $2 \sim 5 \%$ 程度の報告が多く, 著者らの検討結果もそれ とほ汴一致している。

噴門部癌の特殊性として, (1)高齢の男性に多い. (2) 早期癌では隆起型, 進行癌では限局型が多い. (3)分化 型腺癌が多いといったことが多くの施設で挙げられて いる6). 著者らの検討でも噴門部癌症例の $77.8 \%$ を男 性が占めており，他の領域胃癌に比べ男性の占める割 合が多く, 特に上部胃癌の男性頻度 $56.2 \%$ とは大きな 差が認められた。 また平均年齢は著者らの検討では噴 門部癌で60.9歳であり,これも上部胃癌の平均年齢 53.6 歳に比べ明らかに高齢であり，そのほかの領域胃 癌に比較しても高齢者が多いよらである。

肉眼的病型分類では, 著者らの集計では, Borrmann 1, 2を限局型と取り扱い検討したが，噴門部癌が特に 他領域胃癌に比へ限局型が多いという結果は得られな かった.このことは中あるいは下部に多く発生した 3 領域にまたがる広範漫潤型の症例を除外していること も影響していると思われる。しかし実際 Borrmann 2 とBorrmann 3 のいずれに判定すべきか困難な症例 あ多く，これらの検討をするにあたっては梶谷の分 類8)による限局型, 中間型, 浸潤型に分類し検討した方 が正確かと思われたが，今回検討症例全例にその分類 がなされているわけではないので行っていない.

組織型については，いずれの施設からの報告をみて 子噴門部癌では分化型腺癌の頻度が高いことがいわれ

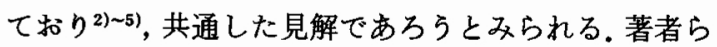
の検討でも噴門部癌では高・中分化型腺癌が $72.2 \%$ と 大多数を占めて扔り，他のいずれの領域に比べてすそ の頻度が高かったが，一方噴門部を除いた上部胃癌で は逆に高・中分化型腺癌が最も少なく，低分化型腺癌， 未分化型癌が最も多く, 胃癌取り扱い上同じ $\mathrm{C}$ 領域の 範疇に入る 2 者の間に顕著な差異を認め, 諸施設の報 告と軌を一にした。

進行程度については，胃癌取り扱い規約上の C 領域 胃癌が M, A 胃癌に比べ進行程度の進んだ症例が多い ということは注湆諸家の報告4)8 で一致した見解と思 われる。しかし C 領域胃癌のうち噴門部癌とそれを除
く上部胃癌についての進行程度の比較については, 噴 門部癌の方に高度進行例が多いといら報告と, ${ }^{5)}$, 逆に 上部胃癌の方に高度進行例が多いといら報告3 あ り，施設により異なった結果が出されている。著者ら の検討では, 噴門部, 上部胃癌ともに stage III ・ IV 症例が70\%を越えており，いずれも中・下部胃癌に比 べ有意に進行癌が多い結果であったが，噴門部癌と上 部胃癌との比較ではやや噴門部癌の方に進行癌が多 かった. 進行程度の決定因子別に検討した結果, 壁深 達度では噴門部癌, 上部胃癌ともに中・下部胃癌に比 べ有意にps (+) 例が多く深達度の進んだ症例が多 かったが，噴門部癌と上部胃癌との比較では噴門部癌 の方が深達度が進んだ症例が多い傾向であった。いず れにせよ噴門部を含めた上部胃癌が他領域胃癌に比べ 浆膜浸潤陽性例が多いという結果は大森ら 5 の報告と 一致している.一方リンバ節転移陽性率は噴門部癌で 最も高率 $(77.8 \%)$ で，中部胃癌で最も低率 $(44.4 \%)$ であったが，中部胃癌を除く領域ではいずれも60\%以 上の転移陽性率を示し差はみられなかった。しかし噴 門部，上部胃癌では手術時すでに $50 \%$ 以上に 2 群以上 リンパ節転移を認め, 他領域に比べ転移が広範であっ た. そこで $R_{2}$ 以上手術例について各りンパ節への転移 状況を検討したが，噴門部癌では丸山ら ${ }^{9) の い う ~ r i g h t ~}$ side flow に沿った転移が中心であるのに対し，上部胃 癌では, right side flowに加兄 left side flow $に$ 沿っ た転移も多く，噴門部癌よりもリンパ節転移が広範で 多方面にわたる傾向がうかがわれた，縦隔内りンバ節 転移陽性率は噴門部癌, 上部胃癌とも $20 \%$ 程度と報告 されている5). 今回著者らの検討例では噴門部癌で開 胸例 3 例中 1 例, 上部胃癌で開胸例 3 例中 1 例飞縦隔 内リンパ節転移を認めているが，いまだ開胸症例が少 なく同部へのリンパ節転移率を論ずる段階には至って いない。

噴門部癌の特徵の一つとして腫瘍が比較的小さくて ๖リンパ節転移や深部浸潤傾向が強いという報告が散 見されるが(0)，その点について著者らも腫場径 $5 \mathrm{~cm}$ 末 満の症例について検討し, 噴門部癌では腫瘍径 $5 \mathrm{~cm}$ 末 満でも半数例ですでに浆膜浸潤を認め, リンパ節転移 陽性で, stage む進んだ症例であることが判明し，また その頻度は上部, 中部, 下部胃癌に比べ明らかに多かっ た。噴門部癌では腫瘍径が小さくても進行した症例が 多いという傾向はこのように著者の検討結果でああら われていた。

以上のように噴門部癌では進行程度が進んだ症例が 
多かったにもかかわらず治瘜切除率は69.4\%と他領域 胃癌に比べ劣る成績ではなかった。非治瘄切除例で非 治癒切除例となった原因を検討すると，食道浸潤の目 測を誤り ow（十）となった症例が $36.4 \%$ と执よんで 扣り，これは今後の反省点としたい。この点について 西ら $\left.{ }^{6}\right)$ は食道漫潤の肉眼判定と組織判定の誤差が限局 型 $1 \mathrm{~cm}$ 以内, 漫潤型が $2 \mathrm{~cm}$ 以内であり，そのことより 術中判断の口側端より限局型 $2 \mathrm{~cm}$, 浸潤型 $4 \mathrm{~cm}$ 離して 切断すればよいとしている、最近著者らるこの方針に 従らか，あるいは術中 ow を迅速組織検査にて確認す るよう心がけている。

噴門部癌の予後について，それを非噴門上部胃癌の 予後と比較した報告が多くみられるが，噴門部癌の方 が予後不良 ${ }^{5)}$, 両者同等 ${ }^{4)}$, 上部胃癌の方が予後不良 ${ }^{6)}$ と 結果はまちまちである．著者らの耐術例についての各 領域胃癌の予後では, 噴門部癌が最も不良で, ついで 上部胃癌, 下部胃癌, 中部胃癌の順で予後不良であ。 た.これをさらに治瘁切除例に限って検討するに, 上 部，中部，下部胃癌ではほぼ同等の70\%前後の良好な 5 生率が得られたのに対し，噴門部癌では依然 $30.3 \%$ と低い生存率であった。一方噴門部癌のうちでも癌の 食道漫潤の程度により予後が左右されることが報告 ${ }^{11}$ されており，著者の検討でも $\mathrm{E}(-)$ 例で $41.6 \%$ の 5 生 率が得られたのに対し，E（+)例では $23.0 \%$ と不良で あった。噴門部癌の予後不良の原因として, 高度進行 例が多いことも一つの原因と考台られるが，今回検討 症例中特に食道浸潤例に対し開胸による縱隔内リンパ 節廓清を行った症例が少なかったことも生存率を低下 させたとも考兄られる。また佐々木ら ${ }^{12}$ は食道胃境界 領域癌で治瘾切除例でも再発死亡例が多いのは食道胃 境界部の後壁剝離面に拈ける癌の露出 (ew) によると しており，そのようなことも原因として考えられる。 今後詳細な再発様式の検討により噴門部癌の予後不良 の原因についてある程度解明できると思われる。

\section{結 論}

広範進展例を除く胃癌手術例891例を噴門部癌, 上部 胃癌, 中部胃癌, 下部胃癌に分け, 年齢, 性別, 手術 結果, 予後などについて検討した結果, 噴門部癌につ
いて以下の特殊性が見いだされた。

1）噴門部癌は高龄の男性に多い.

2) 分化型腺癌が多く, 組織学的に㓡膜浸潤例が多 く, リンパ節転移も高率に認められ高度進行例が多 かった.

3）腫瘍径 $5 \mathrm{~cm}$ 末満の比較的腫場の小さい症例でも すでに禁膜浸潤例が多く, リンパ節転移も高率で高度 進行例が多かった。

4）噴門部癌の予後は不良で, 特に食道浸潤例におい て著明であった。

な拉本論文の内容の一部は第43回胃癌研究会(前橋)に括 いて挠表した。

\section{文献}

1）胃癌研究会編：胃癌取り扱い規約. 改訂第11版, 東 京, 金原出版, 1985

2) 西 满正, 加治佐隆, 阿久根務活か：噴門癌につい て一食道胃境界部癌の提唱一。外科診療 28 ： $1328-1338,1973$

3）西 満正, 加治佐隆, 末永豊邦法か: 食道胃境界領 域癌の特殊性. 手術 $32: 827-833,1978$

4）熊井浩一郎, 吉野肇一, 松本純夫ほ加: 食道胃境界 領域胃癌の予後. 手術 $32: 881-887,1978$

5）大森幸夫, 本田一郎：噴門癌の臨床的特徵。消外 $6: 1417-1422,1983$

6）西 満正, 野村秀洋, 加治佐隆注加: 食道・胃境界 領域癌の外科的治療の問題点. 胃之腸 13 : $1497-1506,1978$

7）梶谷 銀：胃癌の臨床的分類とその意義. 癌 $41: 76-78,1950$

8）石川義信, 角田秀雄, 副島清治ほか：上部胃癌治療 上の特殊性. 臨と研 $47: 1637-1643,1970$

9）丸山圭一, 三輪 潔, 河村 样ほか：噴門部のリン バ流と癌の転移一Lymphographyによる検討一。 胃と腸 $13: 1535-1542 ， 1978$

10）前田芳造：噴門癌の臨床病理学的研究. 日癌治療 会誌 $4: 172-185,1969$

11）大橋一郎, 豊田澄男, 太田博俊注か：食道胃境界部 癌の治療ーリンバ節麀清を中心に一。手術 32 : 835-842, 1978

12）佐々木廸郎, 萩田征美, 及川隆司：食道胃境界領域 癌の予後因子一とくに組織学的癌露出程度につい て一. 日消外会誌 $14: 1543-1548,1981$ 